\title{
Additional tests to investigate neuropathic pain. The value of electroneuromyography for neuropathic pain
}

\author{
Exames complementares na investigação da dor neuropática. O valor da eletroneuromiografia na dor \\ neuropática
}

Fábio Henrique de Gobbi Porto', Gislaine Cristina Lopes Machado Porto², Mario Wilson Lervolino Brotto

DOI 10.5935/1806-0013.20160042

\begin{abstract}
BACKGROUND AND OBJECTIVES: Neuropathic pain is defined as pain induced by injury or disease involving the somatosensory system. Dysfunctions in anatomic regions responsible for the processing of pain may involve peripheral and central nervous system components. A careful history and clinical evaluation with special attention to neurologic propaedeutics are critical for the syndromic, anatomic and etiologic diagnosis of neuropathic pain. However, diagnosis is not always simple and often depends on additional tests. This chapter aimed at reviewing most commonly used additional tests in the clinical practice to help diagnosing neuropathic pain.

CONTENTS: Electroneuromyography is primarily indicated for topographic, etiologic and prognostic diagnosis of peripheral nervous system diseases and for the differential diagnosis between neurogenic, myopathic and neuromuscular junction diseases. It gives real time information on what is going on in the nerve and the muscle, being fundamentally important for differential neuromuscular disease diagnosis. Some imaging methods, such as computerized tomography and magnetic resonance, for their spatial resolution, give details of anatomic structures. Other methods, such as positron emission tomography scan and functional magnetic resonance, in addition to anatomic details, also provide data on metabolic and functional measurements. In addition, imaging techniques such as spectroscopy and diffusion tensor magnetic resonance, allow the study of brain biochemical changes and conectivities with different temporal and spatial resolutions. Other additional tests, such as sensory quantification test and microneurography are seldom used in the clinical practice.

CONCLUSION: Additional tests, together with careful history and neurological evaluation focused on neurologic propaedeutics, may provide important data for the diagnosis of neuropathic pain and are often used in the clinical practice. Keywords: Additional tests, Electroneuromyography, Neuroimaging, Neuropathic pain.
\end{abstract}

\section{RESUMO}

JUSTIFICATIVA E OBJETIVOS: Dor neuropática é definida como a dor causada por lesão ou doença envolvendo o sistema somatossensitivo. Disfunçóes em regióes anatômicas responsáveis pelo processamento da dor podem envolver componentes do sistema nervoso periférico e central. Uma anamnese cuidadosa e um exame clínico com particular atenção na propedêutica neurológica são fundamentais para o diagnóstico sindrômico, anatômico e etiológico das dores neuropáticas. Entretanto, o diagnóstico nem sempre é simples e frequentemente depende do auxílio de exames complementares. O objetivo deste capítulo foi rever os exames complementares mais usados na prática clínica para o auxílio diagnóstico na dor neuropática.

CONTEÚDO: O exame eletroneuromiográfico tem sua principal indicação no diagnóstico topográfico, etiológico e prognóstico das afecçôes do sistema nervoso periférico e no diagnóstico diferencial entre afecçôes neurogênicas, miopáticas

1. Universidade de São Paulo, Faculdade de Medicina, Hospital das Clínicas, Serviço de Neurologia, São Paulo, SP, Brasil.

2. Hospital AC Camargo, Departamento de Radiologia e Imagem, Sáo Paulo, SP, Brasil.

Conflict of interests: none - Sponsoring sources: none.

Correspondence to:

Rua Itapeva 538, conj. 132

01332-000 Sáo Paulo, SP, Brasil.

E-mail: portofhg@gmail.com

(c) Sociedade Brasileira para o Estudo da Dor e da junção neuromuscular. Ele pode fornecer informaçôes em tempo real do que está ocorrendo no nervo e no músculo, sendo de fundamental importância no diagnóstico diferencial das afecçōes neuromusculares. Existem várias modalidades não invasivas de estudo por imagem que podem auxiliar no diagnóstico de quadros de dores neuropáticas. Alguns métodos por imagem como a tomografia computadorizada, ressonância magnética, pela sua resolução espacial, fornecem detalhamento sobre as estruturas anatômicas. Outros métodos como a tomografia computadorizada por emissão de pósitrons, ressonância magnética funcional fornecem além do detalhamento anatômico, dados sobre mensuraçôes metabólicas e funcionais. Além disso, técnicas de imagem como espectroscopia e tensor de difusão por ressonância magnética, permitem estudar alteraçóes bioquímicas e conectividades cerebrais com diferentes resoluçóes temporais e espaciais. Outros exames complementares como teste de quantificação sensitiva e microneurografia são pouco utilizados na prática clínica.

CONCLUSĀO: Exames complementares, em conjunto com uma anamnese cuidadosa e exame neurológico focado na propedêutica neurológica, podem fornecer dados importantes para o diagnóstico de dor neuropática e sấo frequentemente utilizados na prática clínica.

Descritores: Dor neuropática, Eletroneuromiografia, Exames complementares, Neuroimagem.

\section{INTRODUCTION}

Neuropathic pain (NP) is defined as pain induced by injury or disease affecting the somatosensory system ${ }^{1,2}$. Dysfunctions in anatomic regions responsible for the processing of pain may involve peripheral and central nervous systems (PNS, CNS) components. A peripheral neuropathy with NP is an example of PNS injury, while pain secondary to thalamic injury is a CNS injury inducing NP.

NP is object of interest due to its high prevalence affecting approximately 7 to $8 \%$ of the general population and being responsible for 20 to $25 \%$ of chronic pain cases ${ }^{2}$. The condition is characterized by a set of both positive (pain, paresthesia, dysesthesia) and negative (loss of sensitivity, motor, cognitive changes) phenomena, depending on pain location. Careful history and clinical evaluation with special attention to neurologic propaedeutics are critical for neuropathic pain syndromic, anatomic and etiologic diagnosis.

There is no additional exam which alone is able to diagnose NP. However, some additional exams may confirm the presence of the underlying cause of the painful presentation, thus differentiating NP from dysfunctional pain, which is a condition characterized by pain in the absence of identifiable somatic, visceral or neurological injuries.

Imaging exams may, for example, evidence injuries in important regions forof central pain processing (brainstem, thalamus, primary sensory cortex, anterior cingulate gyrus, insula, spinal cord). A major complementary exam for the etiologic investigation of NP is electroneuromyography (ENMG), which examines the function of PNS large myelinated fibers by means of nervous conduction velocities and electromyography ${ }^{3}$. A major limitation is that ENMG has difficulties to evaluate small myelinated and unmyelinated fibers because these are responsible for the transport of information related to pain and temperature sensations.

\section{ADDITIONAL EXAMS}

Electroneuromyography

Electroneuromyography (ENMG) is primarily indicated for topographic, etiologic and prognostic diagnosis of PNS affections and for the differential diagnosis between neurogenic, myopathic and neuromuscular junction affec- 
tions $^{4}$ (Figure 1). ENMG is divided in two parts: nervous conduction study or electroneurography (ENG) ${ }^{5}$ and needle electromyography (EMG).

ENMG is an important method for the differential diagnosis of several muscular and nervous disorders. Computerized tomography (CT) and/or magnetic nuclear resonance (MRI) are just sophisticated pictures, whereas ENMG gives real-time information on what is going on in nerves and muscles and, together with imaging exams helps the accurate diagnosis of neuromuscular disorders ${ }^{6}$.

Electrodiagnostic studies are essential to establish the accurate diagnosis of some diseases not visualized by imaging exams and, in general, one may consider the indication of ENMG when facing decreased sensitivity (hypoesthesia); sensation of shock and tingling (paresthesia); decreased muscle mass (amyotrophy), cramps and/or fasciculations, or decreased or abolished deep reflexes (myotactic hypo or arreflexia) $)^{7,8}$.

The electrodiagnostic study is used to supply accurate diagnosis; to locate the level of the injury; to reconcile treatment with diagnostic correction; to supply prognostic information ${ }^{4,5,9}$.

Soon after anamnesis and neurologic exam, the physician shall develop a differential diagnosis to help identifying nervous and muscle segments to be tested (Figure 2).

Figure 1 is a summary of the electrodiagnostic study process.

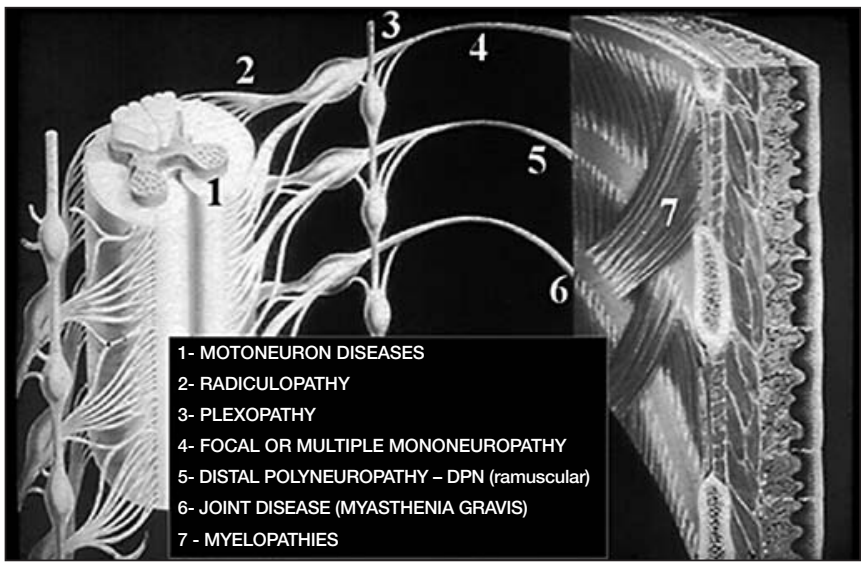

Figure 1. The objective of the electrodiagnostic study is to determine whether there is some abnormality in addition to the injury site along peripheral nervous system pathway.

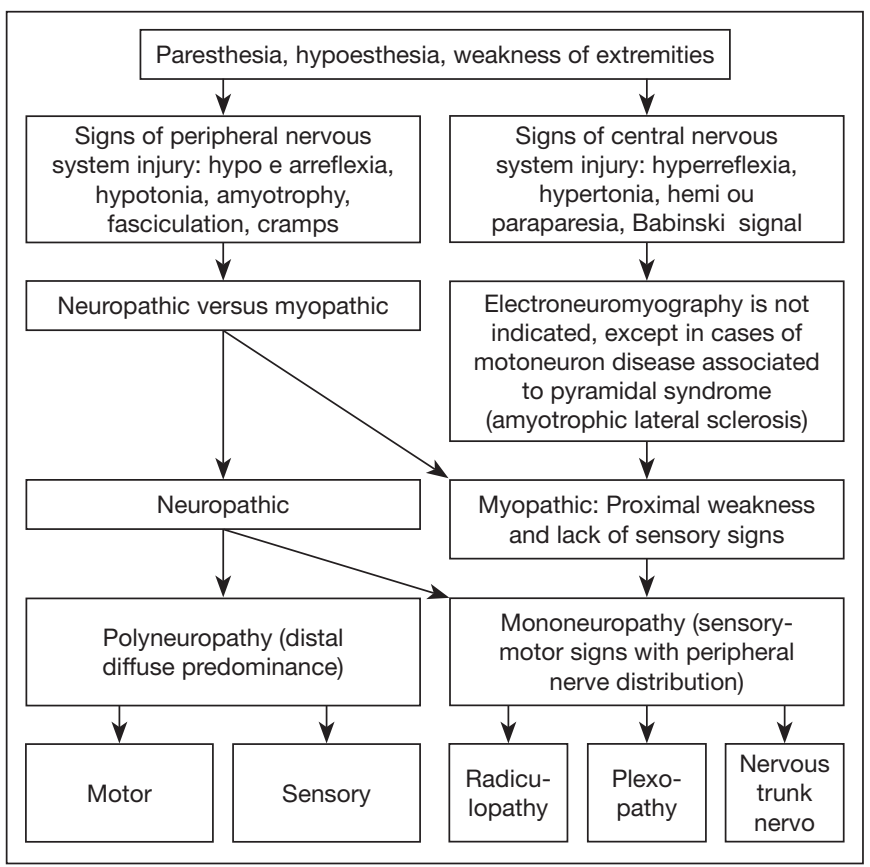

Figure 2. Algorithm for electroneuromyography planning
Examples of most commonly found possible injured sites and differential diagnosis are:

- Spinal cord anterior horn: amyotrophyc lateral sclerosis

- Roots: cervical or lumbosacral radiculopathy;

- Plexopathy: Parsonage Turner syndrome or thoracic outlet;

- Axonal: toxic and/or autoimmune neuropathy (axonal PRN - AMSAN);

- Unmyelinating: metabolic (diabetes mellitus), autoimmune (PRN - Guillain Barré syndrome), degenerative (CMT-I);

- Neuromuscular junction: myastenia gravis, Lambert-Eaton syndrome, botulism;

- Muscular: polymyositis, muscle dystrophies, periodic paralysis.

Aiming at gathering maximum information and perform ENMG with minimum discomfort for patients it is important to have in mind the temporal sequence of events happening when a nerve responds to an injury (Table 1). If the exam is to earlier performed there might be a false negative. Axonal reinnervation has a growth rhythm of approximately $1 \mathrm{~mm}$ per day (approximately $2.5 \mathrm{~cm}$ per month) and if a serial study is being performed for prognosis, it will be necessary to space ENMG time according to axonal regeneration rate.

Table 1. Temporal sequence of post-traumatic electromyographic abnormalities

\begin{tabular}{lc}
\hline Abnormalities & Onset time \\
\hline Conduction block at injury site & Immediate \\
Decreased EP amplitude on distal stimulation & More than 7 days \\
Signs of denervation at rest & 2 to 5 weeks \\
Reinnervation signs (partial injury) & More than 4 to 8 weeks
\end{tabular}

$\mathrm{EP}=$ motor or sensory evoked potential.

In case of suspicion of myopathy, it is fundamental to collect muscle enzymes before ENMG due to muscle trauma of electromyography needle insertion in different points and consequent secondary serum increase of muscle enzymes, in general of mild intensity. Still in case of suspicion of myopathy, the electromyographist shall indicate the best place for muscle biopsy ${ }^{10}$.

Due to multiple traumatic points at electromyography needle insertions, mandatorily the indicated muscle for biopsy shall not be submitted to needling to prevent false results of muscle biopsy. Indication of muscle biopsy in highly affected muscles with severe fibroadipose and/or muscles with questionable or minor EMG changes shall result in inconclusive pathologic changes at muscle biopsy (Table 2).

\section{Neuroimaging Exams}

There are many noninvasive modalities of human brain imaging studies. Some methods, such as CT and MRI, for their spatial resolution, supply details on anatomic structures; other methods, such as positron-emission CT (PET-CT) and functional magnetic resonance (fMRI), in addition to anatomic details also supply data on metabolic and functional measurements. In addition, imaging techniques, such as spectroscopy and diffusion tensor by MRI, allow the study of biochemical changes and brain connectivities with different temporal and spatial resolutions.

\section{Neuroimaging methods versus pain neuroanatomy}

Noninvasive imaging studies, especially PET and fMRI, have helped understanding neural networks and pain pathophysiology, most of them focused on acute pain and few directed to understanding chronic pain associated to central or peripheral neurologic injuries ${ }^{11}$. These studies, focused on determining physiologic pain bases, have shown a pain processing pattern called "pain matrix". Pain matrix involves different areas of the nervous system and of neural networks, which allow the differentiation of pain perceptions. Although some networks are overlapped, NP processing seems to be different from acute pain ${ }^{11}$.

Most widely used modality for the study of pain has been fMRI, for its ability to monitor in real time brain activity during cognitive stimuli and/or tasks. It supplies indirect evaluation of brain metabolism and function by measuring changes in brain oxygenation levels in vivo, by image enhancement called BOLD signal (blood-oxygen-level dependent) ${ }^{12}$.

fMRI resting state supplies information on brain functional connectivity areas. fMRI at rest has the advantage of supplying neuroimaging data of 
Table 2. Muscles - peripheral nerves - spinal level

\begin{tabular}{|c|c|c|}
\hline Muscles & Nerves & Segments \\
\hline Trapezius & Accessorius & C3-C4 \\
\hline Diaphragm & Phrenicus & C3-C4 \\
\hline Rhomboid & Dorsalis scapulae & C5 \\
\hline Anterior serratus & Thoracicus longus & $\mathrm{C} 5-\mathrm{C} 6-\mathrm{C} 7$ \\
\hline Supraspinous & Suprascapularis & C5-C6 \\
\hline Infraspinatus & Suprascapularis & C5-C6 \\
\hline Deltoid & Axillaris & $\mathrm{C} 5-\mathrm{C} 6$ \\
\hline Brachial biceps & Musculocutaneus & C5-트 \\
\hline Brachioradial & Radialis & C5- $\underline{\mathbf{C} 6}$ \\
\hline Brachial triceps & Radialis & C6- \\
\hline Supinator & Radialis & C6- $\mathbf{c 7}$ \\
\hline Extensor carpi radialis & Radialis & C6-C7 \\
\hline Pronator teres & Medianus & $\mathrm{C} 6-\mathrm{C} 7$ \\
\hline Flexor carpi radialis & Medianus & C6- \\
\hline Extensor digitorum communis & Radialis & c7-C8 \\
\hline Extensor indicis proprius & Radialis & C8-T1 \\
\hline Flexor carpi ulnaris & Ulnaris & C8-T1 \\
\hline Flexus policis longus & Medianus & $\mathrm{C} 8-\mathrm{T} 1$ \\
\hline Opponens policis & Medianus & $\mathrm{C} 7-\mathrm{C} 8$ \\
\hline Abductor digiti quinti & Ulnaris & C8-T1 \\
\hline Interosseous dorsalis & Ulnaris & $\mathrm{C} 8-\mathrm{T} 1$ \\
\hline Flexor policis brevis & Medianus & C8-T1 \\
\hline Pronator quadratus & Ulnaris & C8-T1 \\
\hline Iliopsoas & Femoralis & $\underline{\mathrm{L} 2}, \underline{\mathrm{L} 3}, \mathrm{~L} 4$ \\
\hline Abductor of the thigh & Obturatorius & L2, L3, L4 \\
\hline Quadriceps femoris & Femoralis & $\underline{\mathrm{L} 2}, \underline{\mathrm{L} 3}, \mathrm{~L} 4$ \\
\hline Tibialis anterior & Fibularis profundus & $\underline{\text { L4, L5 }}$ \\
\hline Tensor fasciae latae & Gluteus superior & $\underline{\text { L5}}, \mathrm{S} 1$ \\
\hline Biceps femoris & Ischiadicus & $\underline{\text { L5}}, \mathrm{S} 1$ \\
\hline Semitendinosus and membranosus & Ischiadicus & $\mathrm{L} 5, \underline{\mathbf{S 1}}$ \\
\hline Peroneus longus and brevis & Fibularis superficialis & $\underline{\mathbf{L}}, \mathrm{S} 1$ \\
\hline Extensor hallucis longus & Fibularis profundus & $\underline{\mathbf{L} 5}, \mathrm{~S} 1$ \\
\hline Tibialis posterior & Tibialis posterior & $\underline{\mathbf{L}}, \mathrm{S} 1$ \\
\hline Extensor digitorum brevis & Tibialis profundus & $\underline{\mathbf{L}}, \mathrm{S} 1$ \\
\hline Gluteus maximus & Gluteus inferior & $\mathrm{L} 5, \underline{\mathbf{S 1}}$ \\
\hline Abductor hallucis brevis & Tibialis posterior & $\mathrm{L} 5, \underline{\mathbf{S 1}}$ \\
\hline Gastrocnemius medialis & Tibialis posterior & $\mathrm{L} 5, \underline{\mathbf{S 1}}$ \\
\hline Bulbocavernosus & Pudendus & $\mathrm{S} 2, \mathrm{~S} 3, \mathrm{~S} 4$ \\
\hline Sphincter ani & Pudendus & $\mathrm{S} 2, \mathrm{~S} 3, \mathrm{~S} 4$ \\
\hline
\end{tabular}

individuals with chronic pain while they remain at rest inside the device. So, it allows the evaluation of the brain of chronic and neuropathic pain patients without the need for sensory or cognitive stimulation. It is believed that chronic pain changes the oscillation of some neural networks, especially the default-mode network, which are more active at rest; protrusions and executive networks, which are more active during sensory and tasks stimulation, and networks related to sensory and motor processing ${ }^{12}$.

Neuroimaging studies for NP have been more often performed in patients with painful syndromes of unexplained origin, such as fibromyalgia, complex regional pain syndrome type I (CRP1) and in patients with chronic pain such as low back pain. All imaging studies have shown that chronic pain and its morbidities promote changes in different brain areas ${ }^{13}$.

Response to pain activation has been consistently reported in preferentially some areas, being that no single area is responsible for chronic pain and its morbidities. These areas are: primary and secondary somatosensory cortex (S1 and S2), insular cortex (IC), anterior cyngulos cortex (ACC), motor cortex (MC), pre-frontal cortex (PFC), amygdale, thalamus, hippocampus and cerebellum ${ }^{11-13}$. The activation of lateral thalamus, S1, S2 and anterior IC seems to be associated to pain sensory and discriminative aspects ${ }^{12}$.

ACC, posterior IC and limbic system components seem to be associated to emotional pain component. Some PET studies in patients with allodynia suggest that spontaneous NP is associated to thalamic activity, inferring an emotional pain dimension ${ }^{11}$.

The pre-frontal cortex seems to be related to the cognitive aspect of pain and somatosensory cortex and IC are responsible for pain intensity decoding. Some neuroimaging studies have also shown that in chronic pain situations, such as fibromyalgia and chronic low back pain, there are changes in these areas, suggesting changes in pain intensity processing ${ }^{13}$.

Primary motor cortex and supplementary areas also play a role in chronic pain, such as those related to cerebellum changes, although these cerebellar changes are currently poorly understood ${ }^{11,12}$.

Imaging methods versus clinical neuropathic pain evaluation

Imaging evaluation of NP patients will depend on the type of pain and following a rational criterion for each case to prevent radiation and unnecessary costs.

Neuropathic syndromes related to cranial and facial neuralgias, such as trigeminal, facial and other cranial nerves neuralgia are in general diagnosed and evaluated by history and clinical evaluation. Imaging evaluations are necessary when classic symptoms of trigeminal neuralgia are not clear, in cases of trigeminal neuralgia in young patients or, for example, evaluation of facial nerve neuralgia of central origin. Brain MRI with enhancement and with emphasis on cranial nerves is the most indicated. Fifteen percent of patients with trigeminal neuralgia have altered imaging exams (CT or MRI), being caused by tumors, such as trigeminal Schwannoma (Figure 3) and multiple sclerosis ${ }^{14,15}$.

Although MRI provides a better evaluation of cranial nerves and is more sensitive to evaluate parenchymal injuries, CT is best indicated to determine bone erosions, to evaluate bony labyrinth and tympanic cavity. Very often imaging exams are complementary to the clinical exam to determine injury extension and complications, such as in the following example of a patient with Ramsay Hunt syndrome (Figure 4).

Simple X-rays is the most common imaging modality for the initial evaluation of chronic low back pain. Its major objective is to detect gross/severe structural pathological changes. Simple X-rays findings are not specific; for example, osteoarthritis findings seen in X-rays of patients with radiculopathy may also be seen in totally asymptomatic patients. The opposite is also true; normal exams do not rule out the diagnosis of lumbosacral radiculopathy.

MRI is undoubtedly the best method to evaluate cervical, thoracic and lumbosacral radiculopathies, and plexopathies. However, due to its high cost and low availability, it should be rationally used being reserved as first choice for patients with progressive neurologic deficits, cauda equina syndrome, suspicion of malignancy, inflammatory or infectious disease. In addition, MRI may also be used to plan surgical treatment or modalities such as epidural steroid administration.

CT may also be used for the evaluation of radiculopathies. Although not being the method of choice to evaluate spinal cord and nerves, it allows the evaluation with good anatomic resolution (especially CT multislice modalities) of compressive causes of radiculopathy, spinal canal, foramina and even discs. It is especially important for postoperative evaluation after reconstruction with plates and screws, to evaluate integrity and looseness. Autonomic neuropathic syndromes are also investigated with brain or spine MRI, depending on the dysautonomia clinic. In addition, SPECT and PET exams may identify cardiac sympathetic dysfunction, such as in patients with diabetes mellitus types 1 and 2 .

There are many cancer-related neuropathic syndromes. These neuropathies may result from one or more mechanisms, such as compression, inflammation, infiltration of nerves, trunks, plexuses, bones and meninges. All cancer patients with neuropathic syndromes should be evaluated with CT, MRI, PET and/or scintigraphy. In some cases, simple X-rays shall be adequate to identify skeletal injuries. MRI is more sensitive to detect early bone injuries and for medullary, radicular, plexuses and neural trunks eval- 
uation. CT is more sensitive than X-rays and although less sensitive than MRI for early bone injuries it is less expensive, more available and faster than MRI. Bone scintigraphy is more indicated to evaluate the extension of bone injuries along the body ${ }^{16}$.

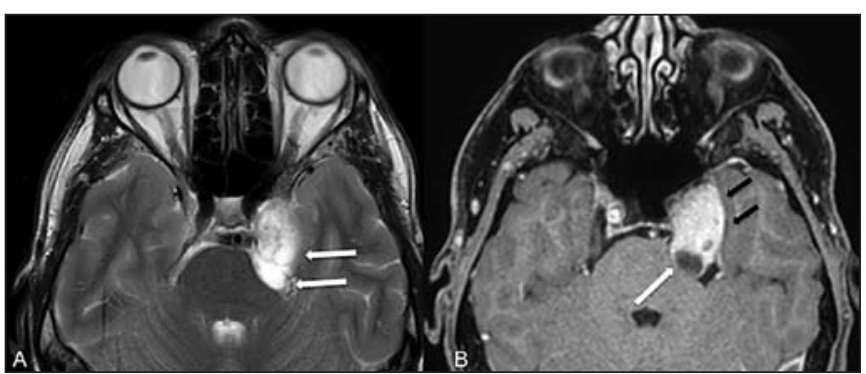

Figure 3. Schwannoma of left trigeminal nerve

A: brain magnetic resonance, T2W1 showing injury with high signal, expansive, in the cisternal portion of the trigeminal nerve, enlarging Meckel's cave, expanding to left cavernous sinus (white arrows). B: brain magnetic resonance, T1W1 with enhancement, showing intense and homogeneous enhancement of the injury (black arrows) with permeating cystic areas (white arrow).

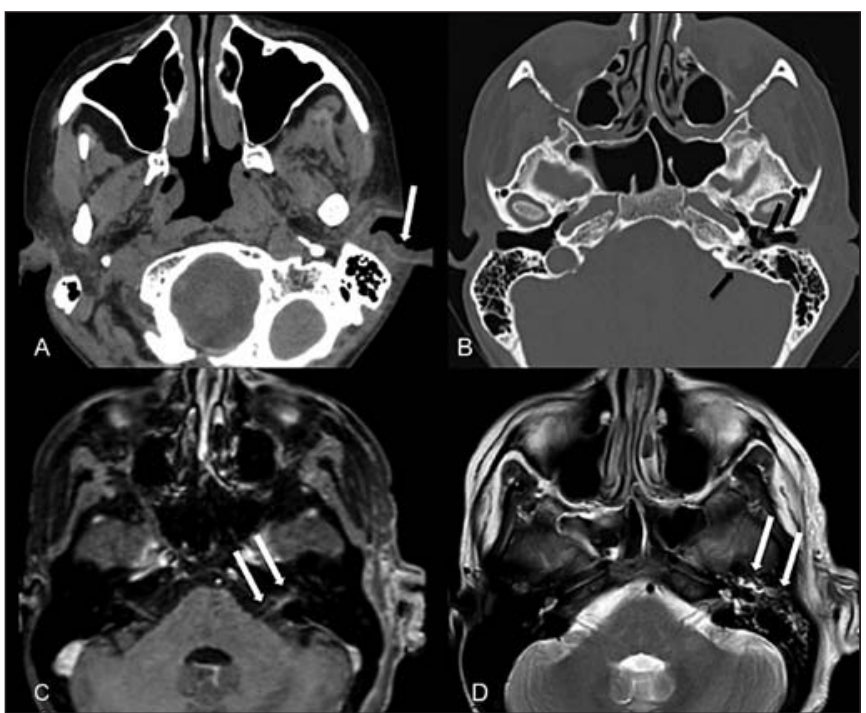

Figure 4. Ramsay Hunt syndrome to the left.

A: brain computerized tomography with enhancement, soft tissues window, showing vesicles in pinna and external ear canal (white arrows). B: brain computerized tomography, bone window, showing extension of vesicles to external ear canal, thickening of tympanic membrane and mastoid cells obliteration. C: brain computerized tomography, T1W1 with enhancement, shows enhancement and thickening of cisternal and canalicular portion of left facial nerve (white arrows). D: brain computerized tomography, T2W1 showing otomastoiditis.

\section{OTHER ADDITIONAL EXAMS}

Sensory quantification test (SQT)

SQT is used to measure sensory perception threshold for different nociceptive pathway modalities (warmth, cold, pain) ${ }^{1,3}$. By means of a thermodo placed on the skin of the region to be tested (areas affected by pain and areas not affected as control), temperature is increased or decreased $\left(1\right.$ to $\left.4^{\circ} \mathrm{C} / \mathrm{s}\right)$ until patients press a button when they feel a certain sensation, thus quantifying the four thermal thresholds of cold, pain by cold, warmth and pain by warmth. SQT is just occasionally used in the clinical practice for cost and applicability reasons.

\section{Microneurography}

This technique is more commonly used in research as compared to clinical practice. It consists of the insertion of a tungsten needle in the nerve to be studied $^{3}$. The pattern of small fibers activity (C fibers) is evaluated by this method. Microneurography is a time consuming and painful method difficult to be evaluated, reasons why it is seldom used in the clinical practice.

\section{CONCLUSION}

Additional exams, together with thorough history and neurologic exam focused on neurologic propedeutics, may supply important data for NP diagnosis and are often used in the clinical practice. It is critical for professionals involved with NP patients care to understand major additional exams and their indications.

\section{REFERENCES}

Bouhassira D, Attal N. Translational neuropathic pain research: a clinical perspective. Neuroscience. 2016; [Epub ahead of print].

Baron R, Binder A, Wasner G. Neuropathic pain: diagnosis, pathophysiological mechanisms, and treatment. Lancet Neurol. 2010;9(8):807-19.

Schestatsky P. Definiçáo diagnóstico e tratamento da dor neuropática. Rev HCPA 2008;28(3):177-87. Aminoff MJ. Electromyography in clinical practice. $2^{\text {nd }}$ ed. New York: Churchill Livingstone; 1987. Downie A W. Studies in nerve conduction. In: Walton JN (ed.). Disorders of voluntary musck. $3^{\text {nd }}$ ed. Edinburgh: Churchill; 1974. 973-1002p.

Johnson EW. Practical electromyography - $4^{\text {th }}$ ed. Lippincott Williams \& Wilkins, 1997.

Kimura J. Nerve conduction and electromyography. In: Dick PJ, Thomas PK, Lambert EH, Bunge R, (eds.). Peripheral neuropathy. $2^{\text {nd }}$ ed. Philadelphia: Saunders; 1984. 919-66p.

Kimura J. Electrodiagnostic in diseases of nerve and muscle: principles and practice. $2^{\text {nd }}$ ed. Philadelphia: Davis; 1989.

9. Victor M, Ropper H. Adams and Victor's - Principles of neurology. $7^{\text {th }}$ ed. New York: McGraw-Hill 2001.

10. WeissL. Easy EMG. Edited by Butterworth Heinemann, 2004.

11. Moisset X, Bouhassira D. Brain imaging of neuropathic pain. Neuroimage. 2007;37(Suppl 1):S80-8

12. Geha PY, Apkarian AV. Brain imaging findings in neuropathic pain. Curr Pain Headache Rep. 2005;9(3):184-8

13. Katherine T Martucci, Pamela NG, Mackey S. Neuroimaging chronic pain: what have we learned and where are we going? Future Neurol. 2014;9(6):615-26.

14. Eller JL, Raslan AM, Burchiel KJ. Trigeminal neuralgia: definition and classification. Neurosurg Focus. 2005;18(5):E3.

15. Majoie CB, Hulsmans FJ, Castelijns JA, Verbeeten B, Tiren D, van Beek EJ, et al. Symptoms and signs related to the trigeminal nerve: diagnostic yield of MR imaging. Radiology. 1998;209(2):557-62.

16. Berger AM, Shuster Jr JL, Von Roenn JH. Principles and practice of Palliative Care and Supportive Oncology, chapter 1: difficult pain syndromes: neuropathic pain, bone pain, visceral pain. $4^{\text {th }}$ ed. Philadelphia, USA: Wolters Kluwer Health; 2013. 960p. 